\title{
Performance assessment of evacuated U-tube solar collector: a numerical study
}

\author{
B KIRAN NAIK and P MUTHUKUMAR* \\ Department of Mechanical Engineering, Indian Institute of Technology Guwahati, Guwahati 781039, India \\ e-mail: pmkumar@iitg.ernet.in; pmkumariitg@gmail.com
}

MS received 2 August 2017; revised 22 June 2018; accepted 10 July 2018; published online 8 January 2019

\begin{abstract}
This paper presents a finite element method based three-dimensional thermal model for predicting the performance of evacuated U-tube solar collector. Numerically predicted working fluid outlet temperature is compared with the experimental data available in the literature and a good agreement is observed between them. The influence of average solar irradiance on efficiency and useful heat gain rate of the solar collector is studied for two different evacuated tube configurations. Employing water and air as working fluid, copper, aluminium and brass as U-tube material, and graphite, magnesium oxide and aluminium oxide as filler material and the performance of the evacuated tube solar collector is investigated in detail.
\end{abstract}

Keywords. Numerical model; evacuated tube solar collector; useful heat gain rate; filler material; U-tube material; working fluid.

\section{Introduction}

In recent times, due to global warming and projected depletion of fossil fuel reserves, utilization of renewable energy receives more attention. In this context, solar energy is projected as one of the most reliable sources of alternative energy due to its abundant availability in several regions. In order to utilize solar energy in a most efficient way, several possible technologies have been explored over the last three decades.

Evacuated tube solar collector is a device which is used to deliver heat at relatively high temperature for various applications including water heating, air-conditioning, etc. This collector can achieve temperatures above $120^{\circ} \mathrm{C}$ [1], due to the combined effects of highly selective surface coating and vacuum insulation. Although many methods are available for heating the working fluid, evacuated tube solar collector is more attractive due to its capability of achieving both high temperature and high thermal efficiency. Also, they are cost effective, reliable and have a reasonably long lifetime.

The schematic of an evacuated U-tube solar collector is shown in figure 1. It consists of outer glass tube, inner glass tube, copper or aluminium fin and U-shaped copper tube. The incident solar radiation falls on the outer surface of the outer glass tube is transferred to the inner glass tube and is absorbed by the fin. The energy collected by the fin is transferred by conduction to the U-tube, and from there to

*For correspondence the working fluid which is flowing inside the U-tube by convection.

The study on heat transfer occurring in an evacuated tube solar collector was initiated during 1970s. The first mathematical model for heat transfer analysis and performance predictions of the aforementioned collector was reported by Eberlein [2] using air as working fluid. The author found that the overall heat loss was very small in the collector due to the evacuated annular space between the glass tubes. Zhiqiang et al and Morrision et al [3-5] investigated the natural circulation flow in the collector tube using water as working fluid. They concluded that buoyancy effect and mass flow rate inside the tube played a significant role in heat transfer process. Hazami et al [6] and Nkwetta et al [7] studied the thermal performance of water in an evacuated tube solar collector with different inner glass surface coating. Neeraj and Avdhesh [8] experimentally investigated the performance of two types of evacuated tube solar collectors, viz. first like the above described one and second with a LHS integrated to the collector tube of the working fluid. From the experimental studies, they have observed that the outlet temperature of the working fluid was higher with LHS than without LHS. Badar et al [9] evaluated the overall heat transfer coefficient of an evacuated U-tube collector both theoretically and experimentally and reported that the numerically predicted overall heat transfer coefficient has good agreement with the experimental data. Gao et al [10] proposed a new mathematical model for predicting the thermal performance of an evacuated U-tube solar collector by taking into account the temperature distribution along the tube radius and axis, and validated their 
(a)

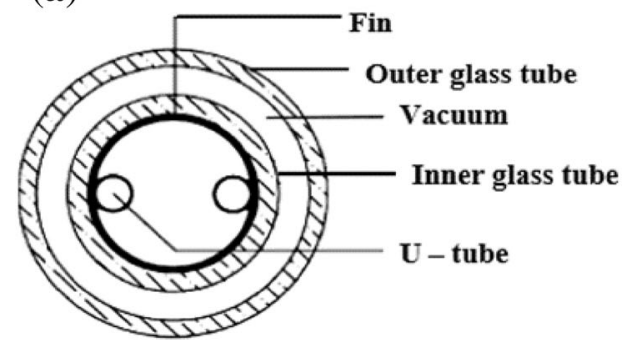

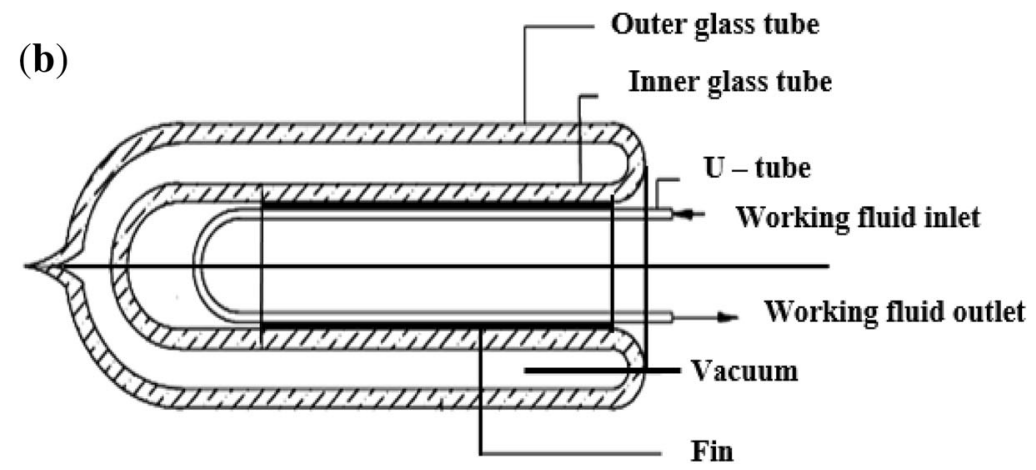

Figure 1. Schematic of evacuated U-tube solar collector. (a) Cross section and (b) longitudinal section.

model with experimental data obtained using aluminum as a fin. They investigated the dependence of thermal efficiency on ambient condition and tube design parameters. Kiran et al [11] developed an analytical solution for predicting the thermal performance of an evacuated tube solar collector by employing three different working fluids. Ayala et al [12] numerically studied the evacuated U-tube solar collector for a special case where the working fluid inlet temperature is less than the ambient temperature. They also predicted the outlet temperature of the heat transfer fluid using two different models, viz. the Boussinesq approximation (BA) model and the variation of thermo physical properties of the temperature (VPT) model. They concluded that the BA model has a closer match for both thermal efficiency and outlet temperature compared to the VPT model.

It is seen from the literature that very few numerical models were developed for predicting the thermal performance of the evacuated U-tube solar collector [2, 4, 9-12]. None of the reported models considered the heat transfer processes occurring across the entire geometry of the evacuated tube solar collector (outer and inner glass tube, absorber tube and U-tube) [4-12]. Most of the reported models analyzed only the transfer processes along the U-tube collector by taking simplified assumptions where the thermal performance of the whole evacuated U-tube solar collector were not predicted and visualized. Also, most of the author's developed the two-dimensional numerical models and no one has reported the three-dimensional numerical study on entire cross-sectional area of the evacuated tube solar collector. Further, there is a lack of profound performance analysis on evacuated U-tube solar collector with different working fluid and U-tube material combinations.

Most of the reported studies were focused on analyzing the performance of the solar collector using different tube designs and absorber coating materials and very few has investigated the effect of filler material (filled inside the absorber/inner tube) on collector efficiency of the evacuated tube. Therefore, in the present study, three-dimensional finite element method based thermal model is developed for predicting the outlet temperature of the working fluid, useful heat gain and efficiency of the solar collector. The proposed model analyzes the heat transfer characteristics of the evacuated U-tube solar collector in both longitudinal and transverse directions. Present model also predicts the working fluid temperature variation and useful heat gain along the collector length. Effect of different working fluid and U-tube material combinations on the thermal efficiency of the solar collector are investigated. The influence of flow rate on different working fluid and U-tube material combinations is also examined. Further, the thermal performance of the evacuated tube solar collector using different filler materials is investigated.

\section{Numerical model}

\subsection{Governing equations}

The evacuated tube solar collector is similar to a heat exchanger which absorbs solar energy and transfers it to the working fluid (figure 1). A finite element method based three-dimensional evacuated U-tube solar collector model for both filled and unfilled type are developed based on following assumptions, solid materials (glass, aluminium or copper) and the working fluid are isotropic, steady state fluid flow condition along the U-tube, flow is laminar, only radiative heat transfer takes place across the annular-space between the inner and outer glass tube, air gap between the inner glass surface and fin material (aluminium or copper) is negligible and conductive heat transfer between the fin material and air is negligible, due to low thermal conductivity of air medium.

The continuity and momentum equations (1) and (2) are solved simultaneously for predicting the behaviour of the working fluid flowing inside the U-tube. The energy equation Eq. (7) is solved using the velocity field obtained from the solution of Eqs. (1) and (2). In order to find the temperature distribution of the working fluid, solar irradiation on the surface coating of the inner glass tube and the heat transfers from inner glass tube surface to the solid fin (copper or aluminium), from solid fin to U-tube and from U-tube to the working fluid are considered. The continuity, 
Table 1. Grid size and number of mesh elements for evacuated U-tube models.

\begin{tabular}{|c|c|c|c|c|c|c|c|}
\hline \multirow[b]{3}{*}{ Sl. No. } & \multirow[b]{3}{*}{ Evacuated tube solar collector model } & \multicolumn{4}{|c|}{ Grid size $(\mathrm{mm})$} & \multirow[b]{3}{*}{ Type of mesh element } & \multirow[b]{3}{*}{ No. of mesh elements } \\
\hline & & \multicolumn{2}{|c|}{$\begin{array}{l}\text { Evacuated } \\
\text { tube }\end{array}$} & \multicolumn{2}{|c|}{$\begin{array}{l}\text { U-tube } \\
\text { material }\end{array}$} & & \\
\hline & & Min & $\operatorname{Max}$ & Min & Max & & \\
\hline \multirow[t]{7}{*}{1} & \multirow{7}{*}{$\begin{array}{c}\text { Copper as U-tube material and air as } \\
\text { working fluid (Model A) }\end{array}$} & \multirow[t]{6}{*}{1.26} & \multirow[t]{6}{*}{6.66} & \multirow[t]{6}{*}{0.50} & \multirow[t]{6}{*}{4.65} & Tetrahedral & 736472 \\
\hline & & & & & & Prism & 87788 \\
\hline & & & & & & Triangular & 161465 \\
\hline & & & & & & Quadrilateral & 128 \\
\hline & & & & & & Edge & 10921 \\
\hline & & & & & & Vertex & 72 \\
\hline & & \multicolumn{4}{|c|}{$\begin{array}{l}\text { Total no. of mesh elements } \\
\text { (radial } \times \text { axial) }\end{array}$} & $996846(2716 \times 367)$ & \\
\hline \multirow[t]{7}{*}{2} & \multirow{7}{*}{$\begin{array}{c}\text { Aluminium as U-tube material and Water } \\
\text { as working fluid (Model B) }\end{array}$} & \multirow[t]{6}{*}{1.35} & \multirow[t]{6}{*}{7.51} & \multirow[t]{6}{*}{0.63} & \multirow[t]{6}{*}{5.62} & Tetrahedral & 814873 \\
\hline & & & & & & Prism & 90744 \\
\hline & & & & & & Triangular & 171465 \\
\hline & & & & & & Quadrilateral & 128 \\
\hline & & & & & & Edge & 10991 \\
\hline & & & & & & Vertex & 72 \\
\hline & & \multicolumn{4}{|c|}{$\begin{array}{l}\text { Total no. of mesh elements } \\
\text { (radial } \times \text { axial) }\end{array}$} & $1088273(2857 \times 381)$ & \\
\hline
\end{tabular}

momentum and energy equations for both the filled and unfilled type U-tube solar collectors are solved with an accuracy of $10^{-3}$ using the GRMS solver. In this model, variation of working fluid thermo-physical properties on the temperature are considered.

Continuity equation:

$$
\nabla \cdot \vec{V}=0
$$

Momentum equation:

$$
\rho_{w f} \vec{V}(\nabla \cdot \vec{V})=-\nabla P+\mu \nabla^{2} \vec{V}
$$

Energy equation:

Radiation equation: solid - vacuum interface region

$$
\begin{aligned}
& \text { Outer glass : } \nabla \cdot\left(k_{g} \nabla T\right)=\nabla \cdot \sigma \varepsilon\left(\nabla T^{4}\right) \\
& \text { Inner glass : } \nabla . \sigma \tau \alpha\left(\nabla T^{4}\right)=\nabla \cdot\left(k_{a} \nabla T\right)
\end{aligned}
$$

Conduction equation: solid - solid interface region

Fin $: \nabla \cdot\left(k_{a} \nabla T\right)=\nabla \cdot\left(k_{f} \nabla T\right) \quad$ (without filler material)

Fin $: \nabla \cdot\left(k_{a} \nabla T\right)=\nabla \cdot\left(k_{f} \nabla T\right)+\nabla \cdot\left(k_{f r} \nabla T\right)$

(with filler material)

$$
\text { U-tube }: \nabla \cdot\left(k_{f} \nabla T\right)=\nabla \cdot\left(k_{u} \nabla T\right)
$$

(without filler material)

U-tube $: \nabla \cdot\left(k_{f} \nabla T\right)+\nabla \cdot\left(k_{f r} \nabla T\right)=\nabla \cdot\left(k_{u} \nabla T\right)$

(with filler material)
Convection equation: solid - liquid interface region

$$
\nabla \cdot\left(k_{u} \nabla T\right)=\vec{V} \cdot \nabla \rho_{w f} c_{p, w f} T
$$

\subsection{Boundary conditions}

- The front, back and bottom sides of the evacuated U-tube solar collector are adiabatic.

$$
n \cdot\left(k_{g} \nabla T\right)=0
$$

where ' $n$ ' is the normal vector.

- At upper glass tube surface there is a constant heat input $(\lambda)$.

- The outer surface of the glass tube and the inlet of the U-tube are at ambient temperature $\left(\mathrm{T}_{\mathrm{amb}}\right)$ and the working fluid inlet temperature $\left(\mathrm{T}_{\mathrm{w}, \mathrm{i}}\right)$, respectively.

\subsection{Mesh generation}

Free unstructured triangular mesh has been adapted to ensure that relatively small geometries (U-tube) are discretized with a sufficient number of elements. The grid size for the working fluid is smaller than that for the evacuated tube as it represents a smaller volume. The distribution of elements depending upon the mesh generation is given in tables 1 and 2 . 
Table 2. Total number of grid elements.

\begin{tabular}{lcc}
\hline \multirow{2}{*}{ Grid name } & \multicolumn{2}{c}{$\begin{array}{c}\text { Number of elements } \\
\text { Evacuated U-tube collector model }\end{array}$} \\
\cline { 2 - 3 } & A (material - copper) & B (material - aluminium) \\
\hline $\mathrm{G}_{1}$ & $7,68,437$ & $8,47,052$ \\
$\mathrm{G}_{2}$ & $9,96,846$ & $10,88,273$ \\
$\mathrm{G}_{3}$ & $11,55,344$ & $12,09,828$ \\
\hline
\end{tabular}

\subsection{Performance parameters}

2.4a Useful heat gain rate: The amount of heat absorbed by the working fluid from the evacuated tube solar collector is given as

$$
Q_{u s e f u l}(W)=\dot{m} c_{p, w f}\left(T_{w, o}-T_{w, i}\right)
$$

2.4b Collector efficiency: The thermal performance of an evacuated tube solar collector is represented by the collector efficiency $(\eta)$. It is defined as the ratio of useful heat gained by the working fluid to the product of effective solar radiation incident on the collector $(\lambda)$ and area of the collector $\left(\mathrm{A}_{\mathrm{c}}\right)$.

$$
\eta=\frac{\dot{m} c_{p, w f}\left(T_{w, o}-T_{w, i}\right)}{\lambda \tau \alpha A_{c}}
$$

where average solar irradiance $(\lambda)$ is basically the average of solar intensity measured for onehour duration at a given time interval of five/ten/fifteen minutes.

\section{Validation of developed numerical model}

In order to validate the numerical model, the results obtained for the outlet temperatures of the working fluid from evacuated tube collector are compared with the data reported by Gao et al [10] and Neeraj and Avadhesh [8]. The surface properties and specifications of the models are given in table 3 . The boundary conditions (section 2.2) are applied to the investigated models for numerical validation. The inlet parameters presented in table 4 are taken as initial and boundary conditions. The numerically predicted working fluid outlet temperature shows good agreement with the experimental data reported in the literature $[8,10]$ (table 4). The maximum and mean deviations of the predicted data from experimental values are $2.2{ }^{\circ} \mathrm{C}$ and $-0.03{ }^{\circ} \mathrm{C}$, respectively. In all the 10 cases, the predicted values for working fluid temperature are slightly higher or lower $\left( \pm 2.5^{\circ} \mathrm{C}\right)$ than the experimental values. This small deviation could be due to the variation in thermo-physical properties of the working fluid and experimental uncertainties and due to the assumptions made in the developed model. Figure 2 shows the comparison of the numerically predicted working fluid outlet temperature with the experimental data. The relative deviation between the numerical and the experimental values is within $\pm 2.5^{\circ} \mathrm{C}$.

Figure 3 shows the temperature distribution across the front side of evacuated tube solar collector for case 1 . As expected, maximum temperature is observed at the inner glass surface due to high radiative heat transfer. After attaining theoretical temperature contour variation plot for

\begin{tabular}{|c|c|c|}
\hline Parameters & $\begin{array}{l}\text { Evacuated tube collector } \\
\text { model - A }[8]\end{array}$ & $\begin{array}{c}\text { Evacuated tube collector } \\
\text { model - B [10] }\end{array}$ \\
\hline Outer glass tube diameter $(\mathrm{m})$ & 0.047 & 0.058 \\
\hline Outer glass tube thickness (m) & 0.0012 & 0.002 \\
\hline Outer glass tube transmittance $(\tau)$ & 0.8 & 0.8 \\
\hline Thermal conductivity of glass $(\mathrm{W} / \mathrm{m}-\mathrm{K})$ & 1.2 & 0.74 \\
\hline Inner glass tube outer diameter $(\mathrm{m})$ & 0.037 & 0.047 \\
\hline Inner glass tube thickness (m) & 0.0012 & 0.002 \\
\hline Absorptivity of inner tube $(\alpha)$ & 0.92 & 0.92 \\
\hline Inner glass tube inner surface, emissivity $(\varepsilon)$ & 0.8 & 0.8 \\
\hline Air gap (m) & 0.001 & 0.001 \\
\hline Air thermal conductivity $(\mathrm{W} / \mathrm{m}-\mathrm{K})$ & 0.03 & 0.03 \\
\hline Type of fin & Copper & Aluminium \\
\hline Fin thickness $(\mathrm{mm})$ & 0.6 & 0.25 \\
\hline Thermal Conductivity of fin $(\mathrm{W} / \mathrm{m}-\mathrm{K})$ & 368 & 202 \\
\hline U tube outer diameter $(\mathrm{m})$ & 0.008 & 0.01 \\
\hline $\mathrm{U}$ tube inner diameter $(\mathrm{m})$ & 0.0074 & 0.0095 \\
\hline Collector tube length (m) & 1.5 & 1.8 \\
\hline Working fluid & Air & Water \\
\hline Specific heat at constant pressure $\left(\mathrm{C}_{\mathrm{p}}\right)(\mathrm{kJ} / \mathrm{kg}-\mathrm{K})$ & 1.005 & 4.2 \\
\hline $\begin{array}{l}\text { Heat transfer coefficient between U-tube and working } \\
\text { fluid } h_{c(1-c)}\left(W / m^{2}-K\right)\end{array}$ & 250 & 700 \\
\hline Reynolds number (Re) & $\operatorname{Re}<4000$ & $\operatorname{Re}<4000$ \\
\hline
\end{tabular}

Table 3. Evacuated tube collector dimensions and surface properties. 
Table 4. Comparison of experimental results with the present model.

\begin{tabular}{|c|c|c|c|c|c|c|c|}
\hline \multicolumn{5}{|c|}{ Inlet parameters } & \multicolumn{3}{|c|}{ Outlet parameters } \\
\hline \multirow[t]{2}{*}{ Case } & \multirow{2}{*}{$\begin{array}{l}\mathrm{T}_{\mathrm{amb}} \\
\left({ }^{\circ} \mathrm{C}\right)\end{array}$} & \multirow{2}{*}{$\begin{array}{l}\mathrm{T}_{\mathrm{w}, \mathrm{i}} \\
\left({ }^{\circ} \mathrm{C}\right)\end{array}$} & \multirow{2}{*}{$\begin{array}{c}\dot{\mathrm{m}} \\
(\mathrm{kg} / \\
\mathrm{s})\end{array}$} & \multirow{2}{*}{$\begin{array}{l}\mathrm{S}_{\mathrm{eff}} \\
(\mathrm{W} / \\
\left.\mathrm{m}^{2}\right)\end{array}$} & \multicolumn{3}{|c|}{$\begin{array}{l}\mathrm{T}_{\mathrm{w}, \mathrm{o}} \\
\left({ }^{\circ} \mathrm{C}\right)\end{array}$} \\
\hline & & & & & Exp. & Numerical & difference \\
\hline \multicolumn{8}{|c|}{ Working fluid - Air [8] for evacuated tube collector, Model A } \\
\hline 1 & 32 & 32 & 0.035 & 495 & 39.8 & 37.9 & 1.9 \\
\hline 2 & 34.5 & 34.5 & 0.035 & 662 & 44.5 & 42.3 & 2.2 \\
\hline 3 & 35.5 & 35.5 & 0.035 & 748 & 46.4 & 44.8 & 1.6 \\
\hline 4 & 36 & 36 & 0.035 & 836 & 48 & 45.9 & 2.1 \\
\hline 5 & 34 & 34 & 0.018 & 469 & 39.4 & 40.5 & -1.1 \\
\hline 6 & 35 & 35 & 0.018 & 621 & 42.3 & 44.1 & -1.8 \\
\hline 7 & 36.5 & 36.5 & 0.018 & 758 & 44.3 & 46.4 & -2.1 \\
\hline 8 & 37 & 37 & 0.018 & 813 & 46.4 & 47.5 & -1.1 \\
\hline \multicolumn{8}{|c|}{ Working fluid - Water [10] for evacuated tube collector, Model B } \\
\hline 9 & 23.7 & 22.9 & 0.027 & 926 & 29 & 30.2 & -1.2 \\
\hline 10 & 23.9 & 56.6 & 0.030 & 860 & 61 & 61.8 & -0.8 \\
\hline
\end{tabular}

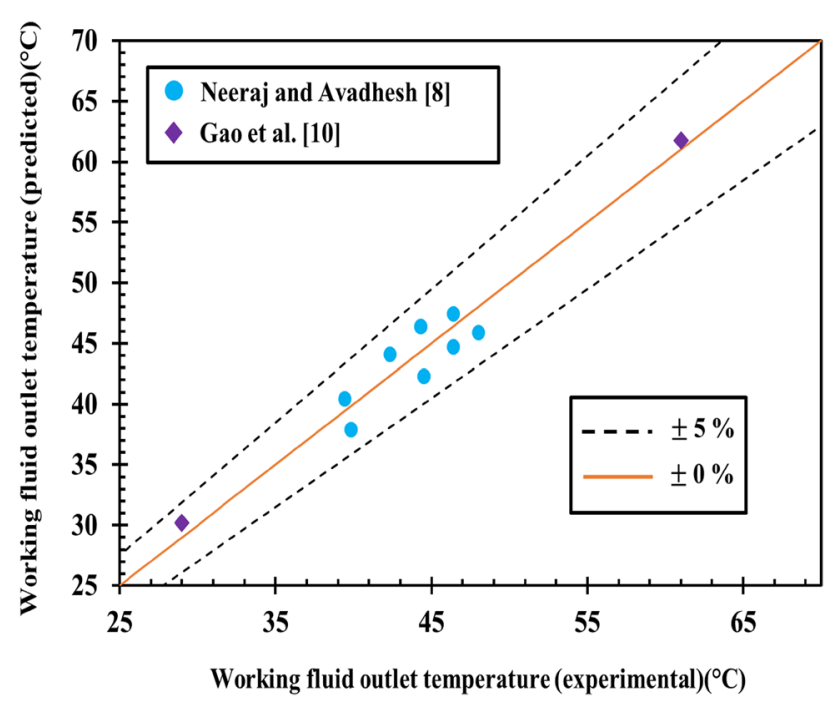

Figure 2. Comparison of numerically predicted working fluid outlet temperature with experimental data $[8,10]$.

whole evacuated U-tube solar collector, individual partwise temperature variation is analyzed along the longitudinal direction and it is observed that there is a significant variation in temperature along the U-tube compared to other parts (aluminium fin and evacuated tube). Therefore, only the contour plot for temperature variation along the length of the U-tube is presented in figure 4.

Figures 5 and 6 show the comparison of experimental results for heat absorption and efficiency with the numerically predicted results. The heat gained by the working fluid increases with increase in average solar irradiance (figures $5 \mathrm{a}-\mathrm{c})$. At higher average solar irradiance, there will be a higher heat transfer from the outer glass to the U-tube (copper or aluminum) and subsequently, a higher potential for convective heat transfer between the U-tube and the

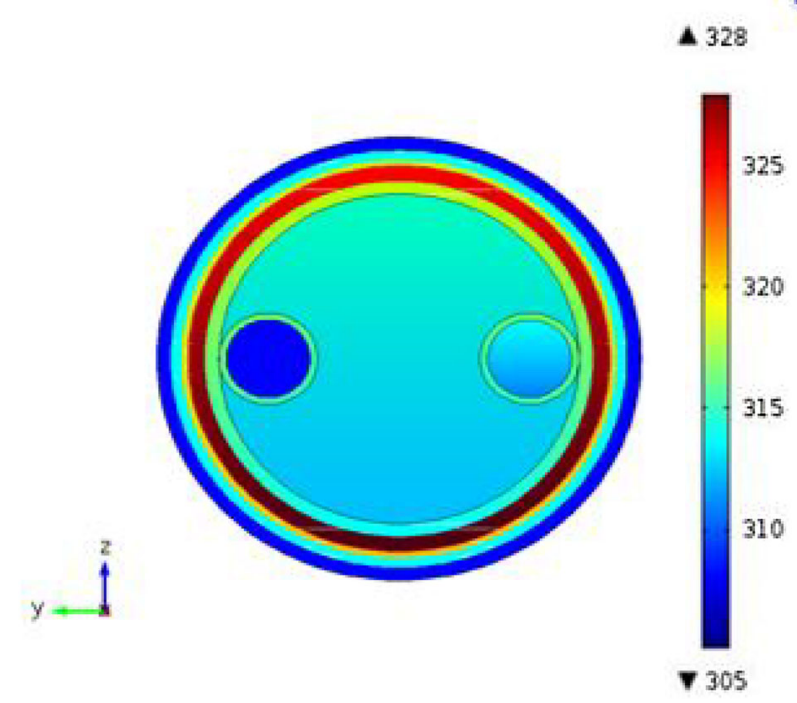

Figure 3. Temperature variation across the evacuated tube solar collector (front view).

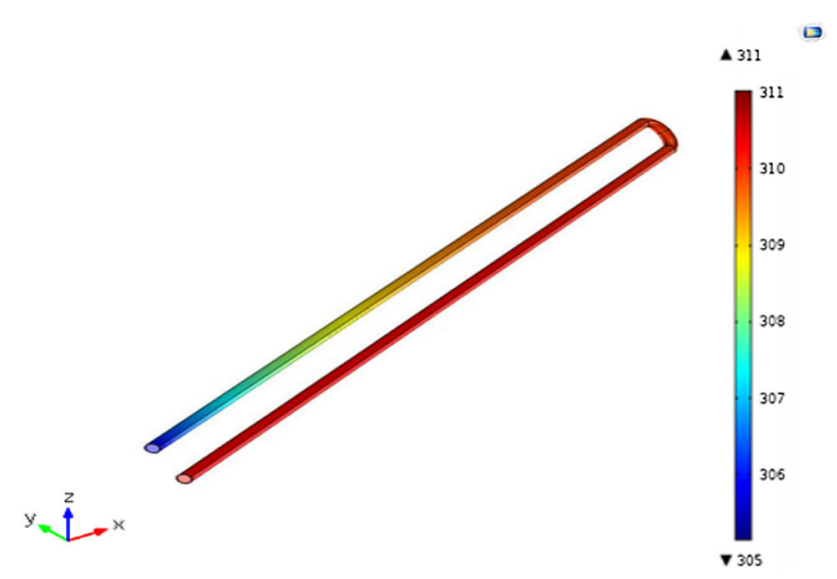

Figure 4. Temperature variation of working fluid along the collector length.

working fluid. It is observed from figure 6(a)-(c) that there is only a minimal increase in efficiency with an increase in average solar irradiance. For a given average solar irradiance, the maximum deviation of predicted data from experimental values for useful heat gained by the working fluid and efficiency of the solar collector are found to be $\pm 7.7 \%$ and $\pm 8.3 \%$ (figures $5 \mathrm{a}-\mathrm{c}$ and $6 \mathrm{a}-\mathrm{c}$ ), respectively.

Based on this preliminary investigation, it is concluded that the proposed numerical model is well-suited for predicting the various performance parameters such as outlet temperature of the working fluid, useful heat gain rate and collector efficiency of the evacuated tube collector.

\subsection{Grid independence test}

As shown in figure 7(a) and (b), a grid independence test is carried out by analysing the effect of different element sizes 

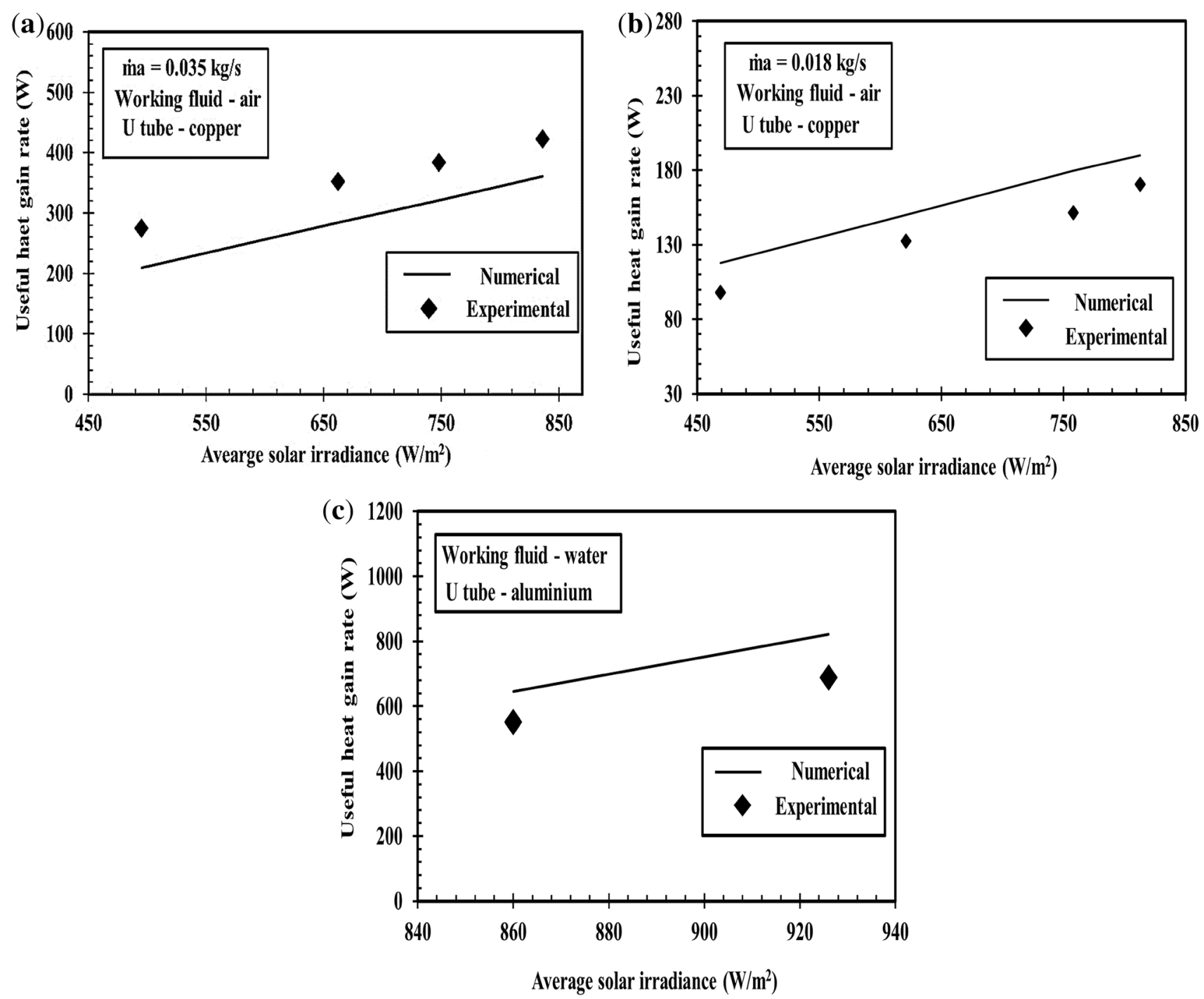

Figure 5. Comparison of numerically predicted heat gain with experimental data [8, 10]. Influence of average solar irradiance on heat gain for working fluid air $[(\mathbf{a})$ and $(\mathbf{b})]$ and water $(\mathbf{c})$.

on the variation of useful heat gain rate along the collector length for both evacuated U-tube solar collector models. The details of grid elements used in both the evacuated U-tube solar collector models (model A and B) are presented in table 1.

From figure 7(a) and (b) and table 1, it is observed that for a given length, there is a remarkable difference in working fluid useful heat gain rate with increase in total grid elements from 7, 68, 437 to $11,55,344$ for the evacuated tube collector model - A (tube material - copper) and $8,47,052$ to $12,09,828$ for the evacuated tube collector model - B (tube material - Aluminium), respectively. By varying the total grid elements from $9,96,846$ to $11,55,344$ for model A and from 10, 88,273 to 12, 09,828 for model B, the variation in useful heat gain rate along the collector length is negligible. Therefore, for saving the computational time, 9, 96,846 and 10, 88,273 elements are selected for further investigation of evacuated U-tube models A and $\mathrm{B}$. The maximum and minimum grid sizes and type of mesh element for the aforementioned grid elements of both the evacuated U-tube collector models (model A and B) are presented in table 2 .

\section{Results and discussion}

With the developed thermal model, the variation in working fluid outlet temperature and useful heat gain rate along the collector length, the influence of mass flow rate on useful heat gain rate along the collector length and the effect of useful heat gain rate on collector efficiency are investigated using two different working fluids (water and air) and three different collector materials (brass, copper and aluminum). Further, the performance comparison of evacuated U-tube 

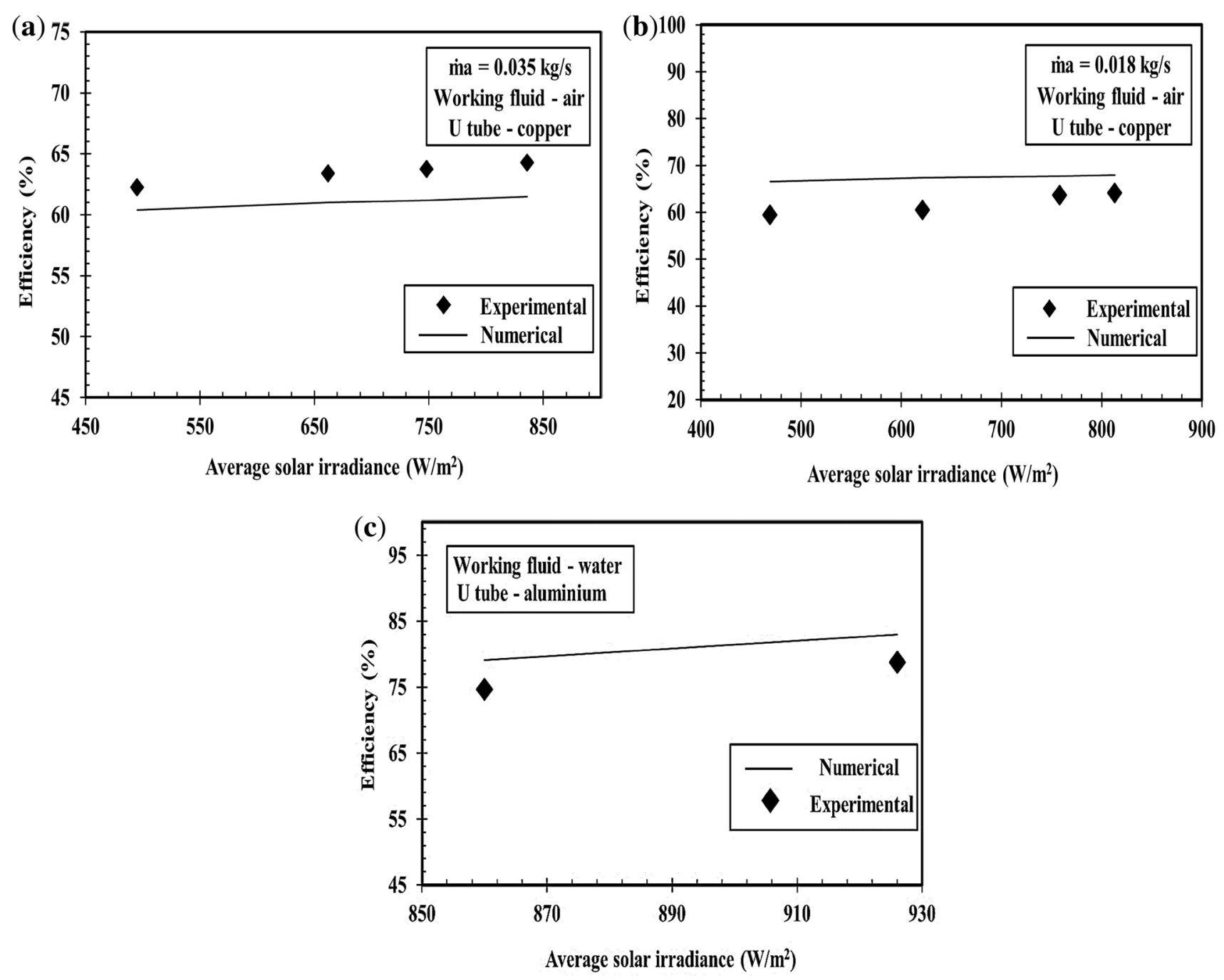

Figure 6. Comparison of experimental results $[8,10]$ with the numerical results. Influence of average solar irradiance on efficiency of the evacuated tube solar collector [air ((a) and (b)) and water $(\mathbf{c})]$.
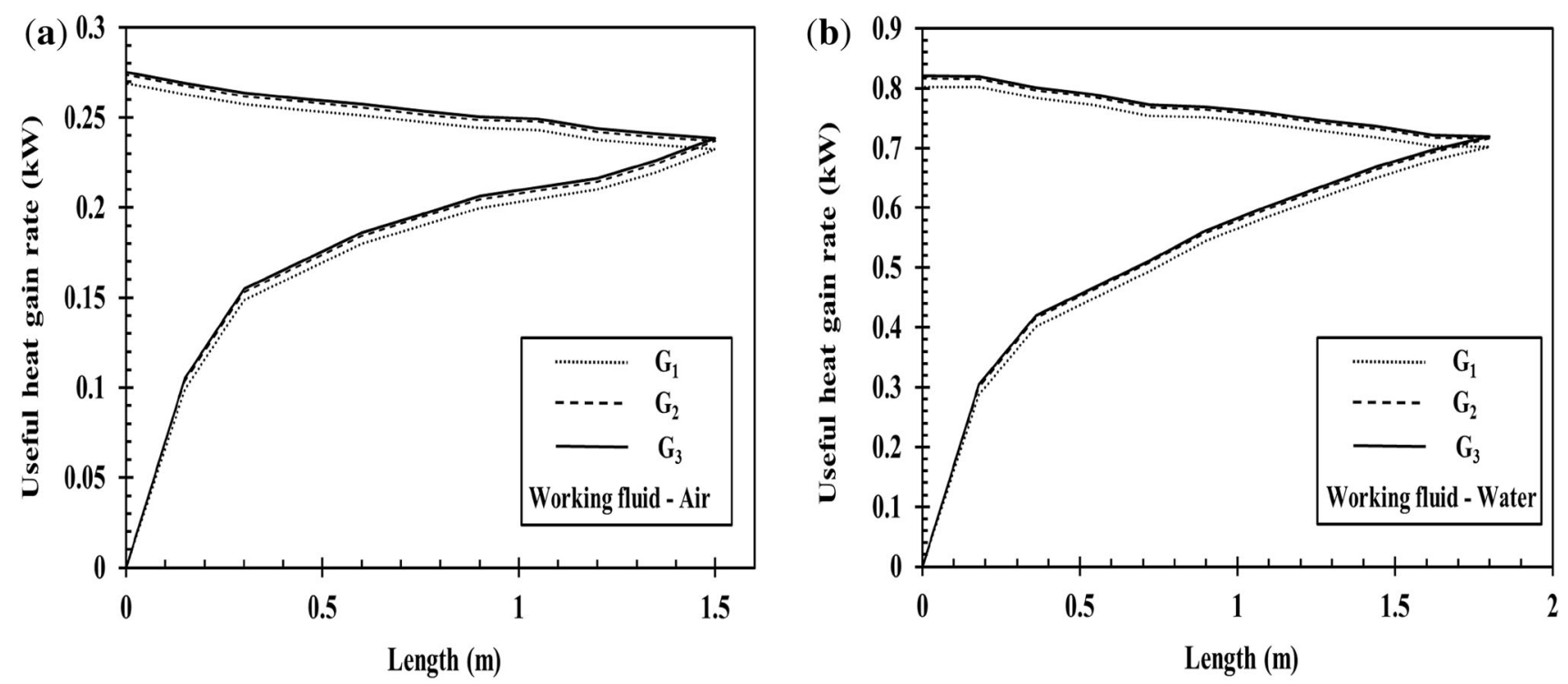

Figure 7. Grid independent test. (a) Evacuated tube model - A. (b) Evacuated tube model - B. 
Table 5. Operating parameters for parametric investigation.

\begin{tabular}{|c|c|c|}
\hline $\begin{array}{l}\text { Sl. } \\
\text { No. }\end{array}$ & Operating parameters & Operating values \\
\hline 1 & $\begin{array}{c}\text { Ambient air temperature } \\
\left({ }^{\circ} \mathrm{C}\right)\end{array}$ & 32 \\
\hline 2 & $\begin{array}{l}\text { Working fluid inlet } \\
\text { temperature }\left({ }^{\circ} \mathrm{C}\right)\end{array}$ & 36 \\
\hline 3 & $\begin{array}{l}\text { Mass flow rate of } \\
\text { working fluid }(\mathrm{kg} / \mathrm{s})\end{array}$ & 0.030 \\
\hline 4 & $\begin{array}{c}\text { Average solar irradiance } \\
\qquad\left(\mathrm{W} / \mathrm{m}^{2}\right)\end{array}$ & 836 \\
\hline 5 & $\begin{array}{c}\text { Dimensions of evacuated } \\
\text { tube collector }\end{array}$ & $\begin{array}{c}\text { Evacuated tube Collector - } \\
\text { Model B (table 3) }\end{array}$ \\
\hline 6 & Working fluid & Water and air \\
\hline 7 & U-tube material & Brass, copper, aluminium \\
\hline 8 & $\begin{array}{c}\text { Thermal conductivity } \\
\text { [13] }(\mathrm{W} / \mathrm{m}-\mathrm{K})\end{array}$ & $\begin{array}{c}\text { Copper }-368 \text { Brass }-109 \\
\text { Aluminium }-202\end{array}$ \\
\hline 9 & Density [13] $\left(\mathrm{kg} / \mathrm{m}^{3}\right)$ & $\begin{array}{c}\text { Copper }-8978 \text { Brass }-7400 \\
\text { Aluminium }-2712\end{array}$ \\
\hline
\end{tabular}

solar collector with filled absorber tube and unfilled absorber tube are also investigated. The list of parameters considered for the present analysis are given in table 5 .

\subsection{Variation of temperature along the collector length}

Figure 8(a) and (b) shows the predicted working fluid temperature variation along the U-tube collector length. For a particular working fluid (air or water), the outlet temperature for copper is higher in comparison with brass and aluminium (figures $8 \mathrm{a}$ and $\mathrm{b}$ ). This is due to the difference in thermal conductivity of the U-tube material. As the copper $\left(\mathrm{k}_{\mathrm{cu}}=401 \mathrm{~W} / \mathrm{m}-\mathrm{K}\right)$ has higher thermal conductivity than brass $\left(\mathrm{k}_{\mathrm{br}}=205 \mathrm{~W} / \mathrm{m}-\mathrm{K}\right)$ and aluminium $\left(\mathrm{k}_{\mathrm{al}}=\right.$ $109 \mathrm{~W} / \mathrm{m}-\mathrm{K})$, by employing copper as a U-tube material will achieve higher heat transfer rate than aluminium and brass as U-tube materials. Therefore, copper as a U-tube material will have less uniformity in temperature along the length when compared to aluminium and brass as the U-tube materials. It is observed from figure 8(a) and (b) that for a given U-tube material, there is a significant increase in working fluid temperature up to certain collector length $(0 \mathrm{~m}$ to approximately $1.6 \mathrm{~m})$ and after that there is only a marginal increase in working fluid temperature along the remaining collector length (approximately $1.6 \mathrm{~m}$ to $0 \mathrm{~m}$ ). This happens because as from 0 to approximately $1.6 \mathrm{~m}$, the difference in working fluid and the U-tube inner wall surface temperature is high. As the working fluid temperature increases, the temperature difference between the working fluid and the U-tube inner wall surface decreases and hence there is only a marginal increase in working fluid temperature.

It is also observed from figure 8(a) and (b) that the difference in outlet temperature between the brass and the copper material based U-tube evacuated tube collector are $7.2{ }^{\circ} \mathrm{C}$ with water as working fluid and $7.0{ }^{\circ} \mathrm{C}$ with air as working fluid. The difference in outlet temperature between the brass and aluminium based U-tube evacuated tube collector are $4.0{ }^{\circ} \mathrm{C}$ with water working fluid and $2.3{ }^{\circ} \mathrm{C}$ with air as working fluid. This indicates that for either water or air as a working fluid, the copper U-tube is a good choice. However, if cost and density of the fin material is an issue then aluminium may be chosen instead of copper by
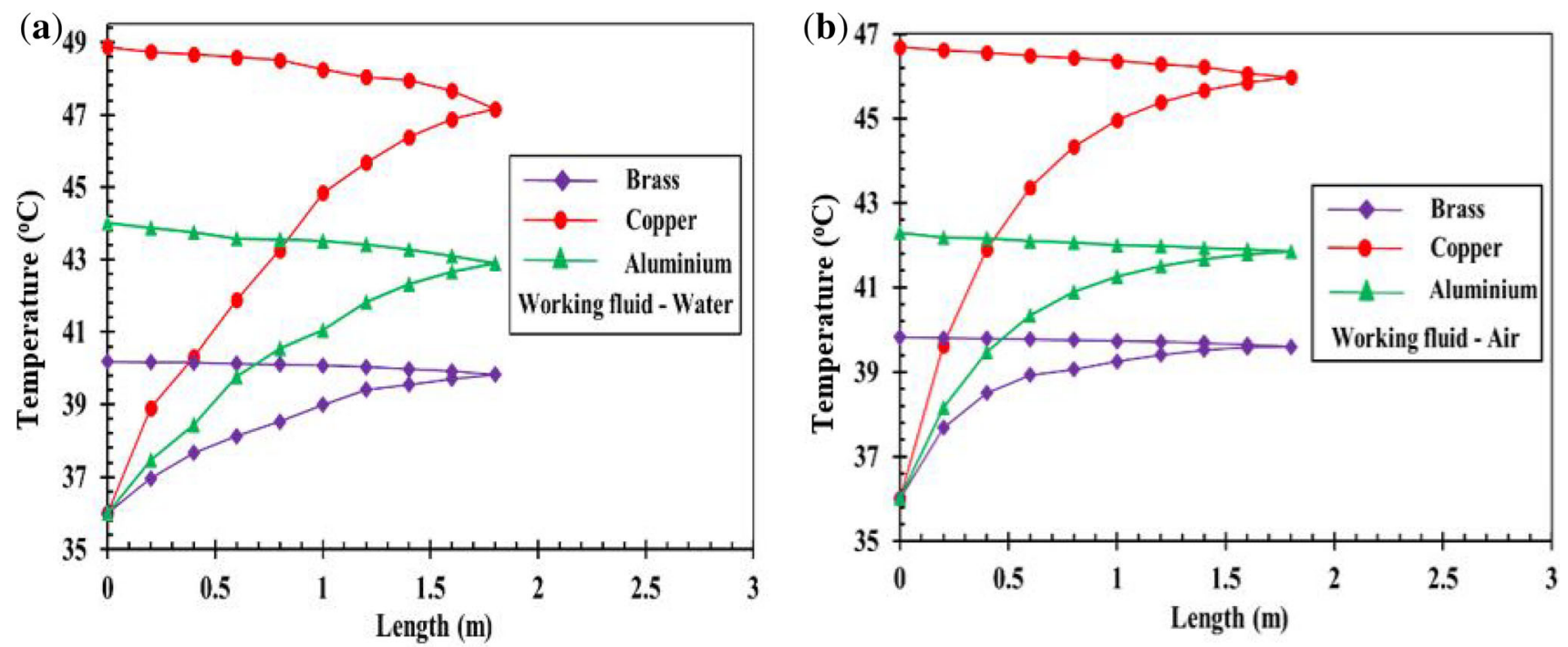

Figure 8. Comparison of working fluid temperature variation along the U-tube collector length for different U-tube materials: (a) Working fluid - water and U-tube material - Brass, Copper and aluminium; (b) Working fluid - air and U-tube material - Brass, Copper and aluminium. 
reducing the aluminium fin thickness because with decrease in thickness of aluminium fin, the same heat transfer rate can be obtained (equivalent to the heat transfer rate from the absorber tube to the copper fin material) from the absorber tube to the aluminium fin. From figure 8(a) and (b), it is also found that for a particular U-tube material, the outlet temperature of water is somewhat higher compared to air.

\subsection{Variation of useful heat gain rate along the collector length}

The variation of the numerically predicted useful heat gain rate of the working fluid along the U-tube collector length is shown in figure 9(a)-(c). It is observed that water gains more heat in comparison with air. This happens because of the difference in specific heat of the working fluid as well as heat transfer coefficient between the U-tube inner surface and the working fluid. It is observed from figure 9(a)(c) that for a given U-tube material, there is a significant increase in the amount of heat absorbed by the working fluid up to certain collector length $(0 \mathrm{~m}$ to approximately $1.6 \mathrm{~m}$ ) and after that there is only a marginal increase in working fluid heat gain along the U-tube collector length (approximately $1.6 \mathrm{~m}$ to $0 \mathrm{~m}$ ). This is due to the fact that, from $0 \mathrm{~m}$ to $1.6 \mathrm{~m}$ collector length, the difference in heat transferred by the U-tube inner wall surface to the working fluid is high. As the heat absorbed by the working fluid increases, the convective heat transfer between the U-tube
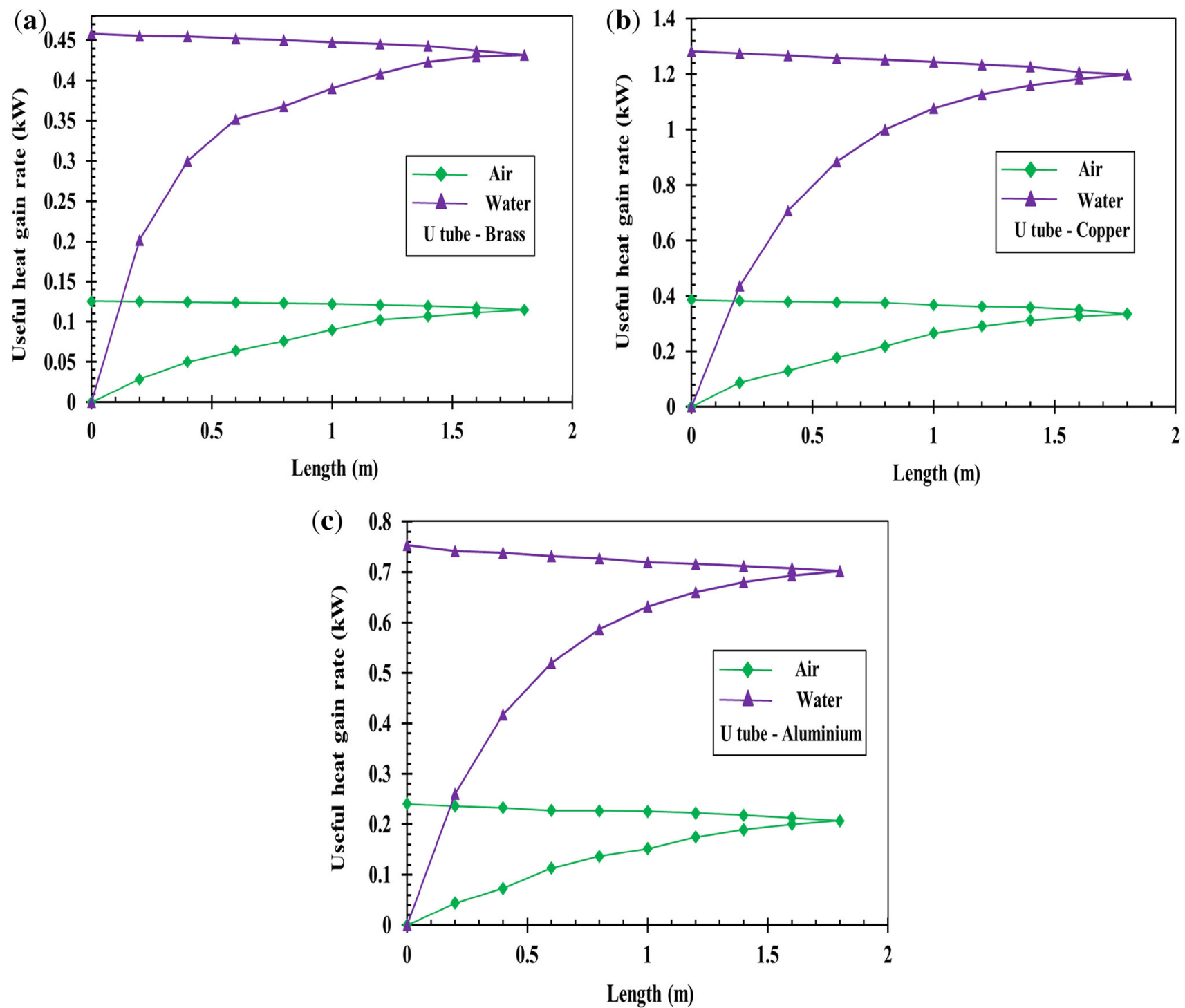

Figure 9. Comparison of working fluid heat gain variation along the collector length for different U-tube materials: (a) U-tube material - Brass and working fluid - air and water; (b) U-tube material - Copper and working fluid - air and water and (c) U-tube material Aluminium and working fluid - air and water. 

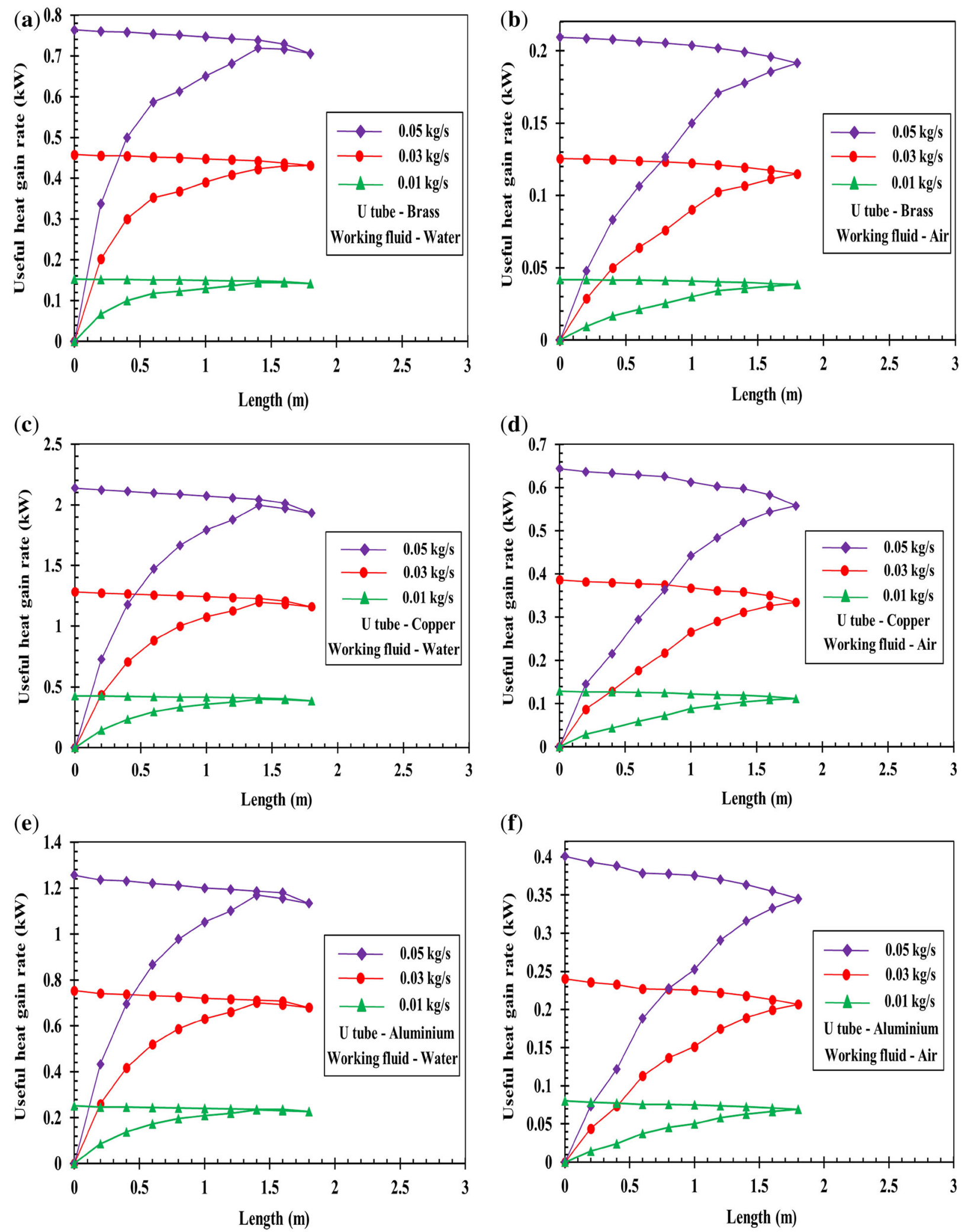

Figure 10. Comparison of working fluid heat gain variation along the U-tube collector length for different mass flow rates: (a) U-tube material - brass and working fluid - water; (b) U-tube material - Copper and working fluid - air; (c) U-tube material - Aluminium and working fluid - water; (d) U-tube material - brass and working fluid - air; (e) U-tube material - Copper and working fluid - water and (f) U-tube material - Aluminium and working fluid - air. 
inner wall surface and the working fluid decreases and hence there is only a marginal increase in heat gained by the working fluid. From figure 9(a)-(c), it is observed that the difference in useful heat gain rate between the air and the water for brass, copper and aluminium U-tube materials is found to be $71 \%, 68 \%$ and $66 \%$, respectively. This indicates that for all the U-tube materials investigated, water is a better working fluid than air.

\subsection{Effect of mass flow rate for different $U$-tube material/working fluid combinations}

Figure 10(a)-(f) illustrates the numerical results obtained for the useful heat absorbed by the water and air at different mass flow rates varying from $0.01 \mathrm{~kg} / \mathrm{s}$ to $0.05 \mathrm{~kg} / \mathrm{s}$ and for different U-tube materials. For a given flow rate, the useful heat absorption rate increases logarithmically from $0 \mathrm{~m}$ to $1.6 \mathrm{~m}$ collector length and then there is a marginal increase (from approximately $1.6 \mathrm{~m}$ to $0 \mathrm{~m}$ ) in heat gain. For a particular collector length, as the flow rate increases, the amount of heat absorbed by the water also increases. This indicates that higher flow rates will absorb more heat from the inner surface of the U-tube, thereby reducing the temperature gradient between U-tube and bulk working fluid, and maintaining constant heat transfer along the collector length. It is observed from figure $10(\mathrm{a}),(\mathrm{c})$ and (e) that for a particular working fluid (water), in order to achieve the high heat gain of about $0.8 \mathrm{~kW}$, the flow rate should be $0.052 \mathrm{~kg} / \mathrm{s}, 0.02 \mathrm{~kg} / \mathrm{s}$ and $0.031 \mathrm{~kg} / \mathrm{s}$, respectively, for brass, copper and aluminium. This implies that for a low thermal conductivity material, with an increase in working fluid flow rate higher heat gain will be attained. From figure 10(a) and (b), it is found that for a particular U-tube material (brass), to achieve heat gain of $0.2 \mathrm{~kW}$, air and water should operate at a flow rate of $0.011 \mathrm{~kg} / \mathrm{s}$ and 0.048 $\mathrm{kg} / \mathrm{s}$, respectively. This indicates that a higher specific heat of the fluid, attains the same heat gain at lower fluid flow rate. For a given collector length, increasing the mass flow from $0.01 \mathrm{~kg} / \mathrm{s}$ to $0.05 \mathrm{~kg} / \mathrm{s}$, improve the useful heat absorption rate by $81 \%, 84 \%$ \& $76 \%$ for water and $81 \%$, $82.5 \%$ and $80 \%$ for air, respectively, for brass, copper and aluminium as U-tube materials.

\subsection{Effect of working fluid/U-tube material combinations on collector efficiency}

The influence of working fluid (water, air) on the efficiency of the evacuated tube solar collector for three different U-tube materials (brass, copper and aluminium) is illustrated in figure 11. From figure 11, it is observed that for a given working fluid, the collector efficiency is found to be high with copper as U-tube material than brass and aluminium and water is found the best choice of working fluid instead of air for a particular U-tube material.

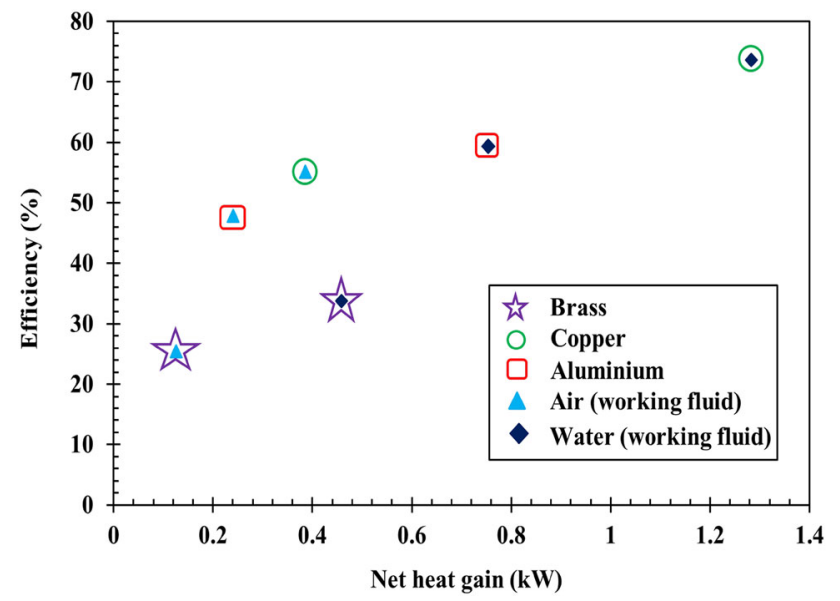

Figure 11. Influence of useful heat gained on efficiency of the evacuated tube solar collector.

\subsection{Influence of filler material on performance of the solar collector}

The numerical model developed in section 2 is used for analysing the performance of the filled type U-tube solar collector. Only difference between the filled and unfilled type U-tube solar collector is filling of filler material (graphite/aluminium oxide/magnesium oxide) instead of air (unfilled) between the U-tube (figure 12). Using the surface properties and dimensions of evacuated collector model - A [10] listed in table 3, a parametric investigation on the influence of a filler material between the U-tube and the absorber surface (copper fin surface) has been carried out (figure 12). Filler material used for performance improvement are magnesium oxide, aluminium oxide and graphite. As the thermal conductivity of air filled space is very low $(0.03 \mathrm{~W} / \mathrm{m}-\mathrm{K})$, the performance of evacuated tube collector filled with high thermal conductivity powders such as aluminium oxide, magnesium oxide and graphite $(30 \mathrm{~W} / \mathrm{m}-\mathrm{K}$, $60 \mathrm{~W} / \mathrm{m}-\mathrm{K}$ and $168 \mathrm{~W} / \mathrm{m}-\mathrm{K}$ ) is expected to be better [13]. Predicted results are presented in figure 13. It is observed that the efficiency with graphite filler material is higher compared to magnesium oxide, aluminium oxide and no filler material. This happens because by employing filler material, the heat transferdue to conduction from inner glass surface to the U-tube increases because of high thermal conductivity of the filler material compared to air (unfilled). As a consequence, the thermal resistance between the inner glass tube and the fin decreases and the useful heat gained by the working fluid due to convective heat transfer from the filled-type U-tube to the working fluid increases. Thus, employing filler material will enhance the heat transfer from inner glass tube surface to the U-tube and improves the performance of the evacuated U-tube solar collector. It is also observed that at normalized heat gain $\left[\left(\mathrm{T}_{\mathrm{m}}-\mathrm{T}_{\mathrm{amb}}\right) / \lambda\right]$, the graphite filler yields $7.8 \%, 12.3 \%$ and $15.3 \%$ higher efficiency than the magnesium oxide 

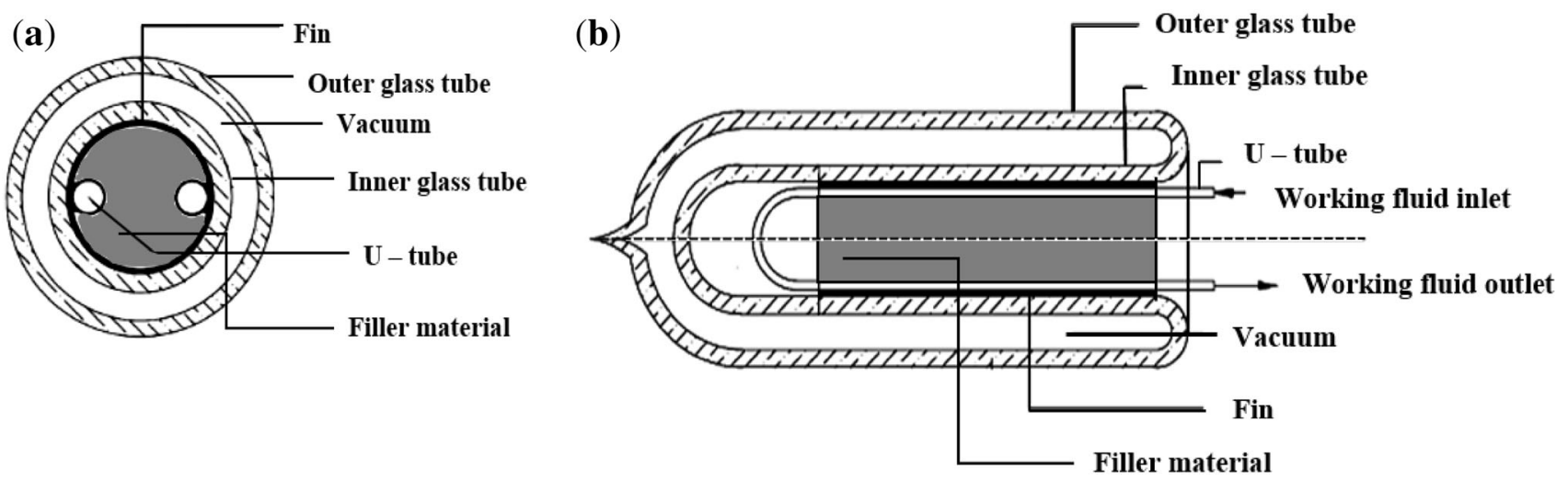

Figure 12. Schematic of filler evacuated U-tube solar collector. (a) Cross section and (b) longitudinal section.

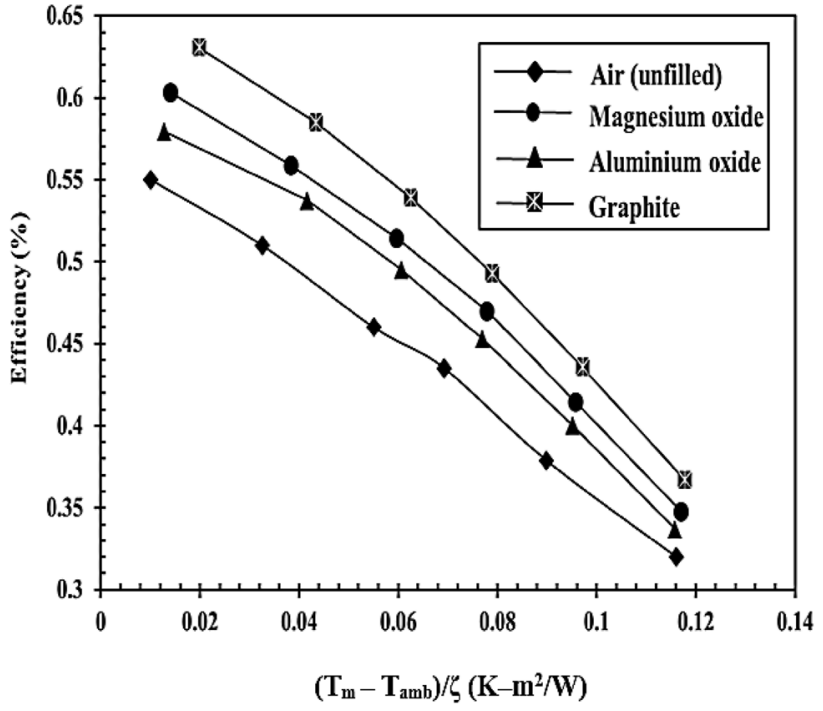

Figure 13. Influence of filler material on evacuated tube solar collector efficiency.

filler, the aluminium oxide filler and the case of no filler (air filled space).

From figure 13, it is concluded that by employing filler material will enhance the heat transfer from inner glass tube surface to the U-tube and improves the performance of the evacuated U-tube solar collector.

\section{Summary and conclusions}

A profound numerical analysis on thermal processes occurring in an evacuated U-tube solar collector is carried out using a 3D numerical model based on finite element method. The performance characteristics of the solar collector, viz. outlet temperature of the working fluid, efficiency and useful heat gain rate of the collector, predicted from the numerical model showed good agreement with the experimental data available in the literature. It is found that the average solar irradiance has a significant effect on the useful heat gained by the working fluid and an insignificant effect on the efficiency of the solar collector. By employing three different U-tube materials (aluminium, copper and brass), two different working fluids (air and water) and three different filler materials (graphite, magnesium oxide and aluminium oxide), the thermal performance of the evacuated tube solar collector is analysed and following conclusions are drawn.

- Copper is the best material compared to brass and aluminium and water is better than air as working fluid.

- For a given U-tube material, with increase in flow rate, the useful heat absorption capacity increases. It is observed that by increasing the flow rate from 0.01 to $0.05 \mathrm{~kg} / \mathrm{s}$, the net heat absorption rate of copper increases by $84 \%$ for water as working fluid and $82.5 \%$ for air as working fluid.

- The performance of low thermal conductive U-tube material can be improved by increasing the flow rate of the working fluid.

- For a given flow rate, the high collector efficiency is achieved for water and copper as working fluid and U-tube material combination and the low collector efficiency is achieved for air and brass as working fluid and U-tube material combination. For the aforementioned working fluid and U-tube material combination, the higher/lower collector efficiency is attained to be $76 \% / 24 \%$.

- Compared to magnesium oxide and aluminium oxide filler material, graphite filler yields higher efficiency. Employing graphite as filler material in between the evacuated tube absorber surface (fin) and the U-tube, the thermal efficiency of the existing evacuated tube solar collector is increased by $15.3 \%$.

Using the developed model, one can design and analyze the performance of an evacuated U-tube solar collector and also visualize the heat transfer processes occurring in 
between the evacuated tube, U-tube and the working fluid. This model can also be used for investigating the performance of the evacuated U-tube solar collector at different operating conditions with different operating parameters.

\section{Nomenclature}

$\mathrm{A}_{\mathrm{c}} \quad$ area of the collector $\left(\mathrm{m}^{2}\right)$

$\mathrm{c}_{\mathrm{p}} \quad$ specific heat at constant pressure $(\mathrm{kJ} / \mathrm{kg}-\mathrm{K})$

$\mathrm{k}_{\mathrm{g}} \quad$ thermal conductivity of the glass tube $(\mathrm{W} / \mathrm{m}-\mathrm{K})$

$\mathrm{k}_{\mathrm{fr}}$ thermal conductivity of the filler material $(\mathrm{W} / \mathrm{m}-$ K)

$\mathrm{k}_{\mathrm{a}} \quad$ thermal conductivity of the inner glass tube/ absorber tube $(\mathrm{W} / \mathrm{m}-\mathrm{K})$

$\mathrm{k}_{\mathrm{f}} \quad$ thermal conductivity of the fin material $(\mathrm{W} / \mathrm{m}-\mathrm{K})$

$\mathrm{k}_{\mathrm{u}}$ thermal conductivity of the U-tube $(\mathrm{W} / \mathrm{m}-\mathrm{K})$

LHS latent heat storage

$\dot{\mathrm{m}} \quad$ mass flow rate $(\mathrm{kg} / \mathrm{s})$

$\mathrm{P} \quad$ pressure $(\mathrm{Pa})$

$\mathrm{Q}_{\text {useful }}$ useful heat gained by the working fluid (W)

$\mathrm{T}$ temperature $\left({ }^{\circ} \mathrm{C}\right)$

$\vec{v} \quad$ velocity $(\mathrm{m} / \mathrm{s})$

\section{Greek letters}

$\alpha$ absorptivity of the inner glass tube/absorber tube

$\lambda$ average solar irradiance $\left(\mathrm{W} / \mathrm{m}^{2}\right)$

$\rho$ density $\left(\mathrm{kg} / \mathrm{m}^{3}\right)$

$\mu$ dynamic viscosity of working fluid ( $\mathrm{Pa}-\mathrm{s})$

$\varepsilon \quad$ emissivity of the outer glass tube

$\eta \quad$ solar collector efficiency $(\%)$

$\sigma \quad$ Stephen Boltzmann constant $\left(\mathrm{W} / \mathrm{m}^{2}-\mathrm{K}^{4}\right)$

$\tau$ transmissivity of the inner glass tube/absorber tube

\begin{tabular}{ll}
\multicolumn{2}{l}{ Subscript } \\
amb & ambient air \\
ini & initial \\
i & inner \\
o & outer \\
w,o & working fluid outlet \\
w,i & working fluid inlet \\
wf & working fluid
\end{tabular}

\section{References}

[1] Harding G, Zhiqiang Y and Mackey D W 1985 Heat extraction efficiency of a concentric glass tubular evacuated collector. Int. J. Solar Energy 35: 71-79

[2] Eberlein M B 1976 Analysis and Performance Predictions of Evacuated Tubular Solar Collectors using Air as the Working Fluid. University of Wisconsin

[3] Zhiqiang Y, Harding G and Window B 1984 Water-in-glass manifolds for heat extraction from evacuated solar collector tubes. Int. J. Solar Energy 32: 223-230

[4] Morrison G, Budihardjo I and Behnia M 2004 Water-in-glass evacuated tube solar water heaters. Int. J. Solar Energy 76: $135-140$

[5] Morrison G, Budihardjo I and Behnia M 2005 Measurement and simulation of flow rate in a water-in-glass evacuated tube solar water heater. Int. J. Solar Energy 78: 257-267

[6] Hazami M, Naili N, Attar I and Farhat A 2013 Solar water heating systems feasibility for domestic requests in Tunisia: thermal potential and economic analysis. Int. J. Energy Convers. Manage. 76: 599-608

[7] Nkwetta D N, Smyth M, Zacharopoulos A and Hyde T 2013 Experimental performance evaluation and comparative analyses of heat pipe and direct flow augmented solar collector. Int. J. Appl. Therm Eng. 60: 225-233

[8] Neeraj M and Avadhesh Y 2015 Experimental analysis of thermal performance of evacuated tube solar air collector with phase change material for sunshine and off sunshine hours. Int. J. Amb. Energy 2162-8246

[9] Badar A W, Buchholz R and Ziegler F 2011 Experimental and theoretical evaluation of the overall heat loss coefficient of vacuum tubes of a solar collector. Int. J. Solar Energy 85: 1447-1456

[10] Gao Y, Fan R, Zhang X Y, An Y J, Wang M X, Gao Y K and $\mathrm{Yu}$ Y 2014 Thermal performance and parameter analysis of a U-pipe evacuated solar tube collector. Int. J. Solar Energy 107: 714-727

[11] Naik B K, Vrashney A, Muthukumar P and Somayaji C 2015 Modelling and performance analysis of $U$ type evacuated tube solar collector using different working fluids. Energy Procedia 90: 227-237

[12] Ayala J A A, Rodriguez G M, Nunez M P, Ramirez A R U and Munoz A G 2015 Numerical study of a low temperature water-in-glass evacuated tube solar collector. Int. J. Energy Convers. Manage. 94: 472-481

[13] Young H D 1992. University Physics 7th Ed. Boston, United states: Addison Wesley, pp 192-194 